\title{
Physical activity and quality of life in persons with visual impairment: an observational study
}

\author{
Atividade física e qualidade de vida em pessoas com deficiência visual: \\ um estudo observacional
}

\author{
Nayron Medeiros Soares (D) $1 \bowtie$, Gabriela Magalhães Pereira (D) 1, Lauriston Emmanoel Barros Soares (D) 2 , \\ Narrycia Medeiros Soares $(\mathbb{D})^{3}$, Capitulino Camargo Junior (D) 4, Elizaete de Lima Medeiros Oliveira (D) ${ }^{2}$ \\ ${ }^{1}$ Faculty of Medicine, Federal University of Rio Grande do Sul. Porto Alegre, Rio Grande do Sul, Brazil. \\ 2 Center of Biological and Health Sciences, State University of Paraíba. Campina Grande, Paraíba, Brazil. \\ ${ }^{3}$ Physiotherapy Department, University Center Maurice of Nassau. João Pessoa, Paraíba, Brazil. \\ ${ }^{4}$ Department of Medicine, Federal University of Health Science of Porto Alegre. Porto Alegre, Rio Grande do Sul, Brazil.
}

How to cite this article:

Soares NM, Pereira GM, Soares LEB, Soares NM², Camargo Junior C, Oliveira ELM. Physical activity and quality of life in persons with visual impairment: an observational study. Sci Med. 2019;29(3):e33838. http://doi.org/10.15448/1980-6108.2019.3.33838

\section{ABSTRACT}

AIMS: Little evidence demonstrates the influence of physical activity habits on the quality of life of people with visual impairment (VI). To gain a broader understanding, this study attempted to verify the relation between the habits of physical activity and quality of life in people with VI. METHODS: The sample consisted of 53 visually impaired volunteers. The Clinical and Sociodemographic Assessment Sheet, the International Physical Activity Questionnaire short version and the Quality of Life Assessment Instrument (WHOQOL-Bref) were used.

RESULTS: The mean age was 42.39 \pm 2.10 years, with a predominance of males and the mean Body Mass Index was 27.55 \pm 0.76 . Predominant physical activity levels were between moderate to high. Males presented significantly higher levels of vigorous physical activity ( $\mathrm{p}=0.033$ ) and higher scores in WHOQOL-Bref, when compared to the female sex.

CONCLUSION: The higher the physical activity levels of this population with VI, the better the quality of life. The participants had a predominance of moderate to high physical activity, as well as, the male presented higher levels of physical activity, when compared with the female in vigorous activities.

KEYWORD: Exercise; blindness; disabled persons; quality of life.

\section{RESUMO}

OBJETIVOS: Pouca evidência demonstra a influência dos hábitos de atividade física na qualidade de vida de pessoas com deficiência visual. A fim de alcançar uma compreensão maior sobre o tema, este estudo procurou verificar a relação entre os hábitos de atividade física e a qualidade de vida de pessoas com deficiência visual.

MÉTODOS: A amostra foi composta por 53 voluntários com deficiência visual. Utilizou-se a ficha de avaliação sociodemográfica e clínica, a versão curta do Questionário internacional de atividade física e o Instrumento de Avaliação da qualidade de vida (WHOQOL-Bref).

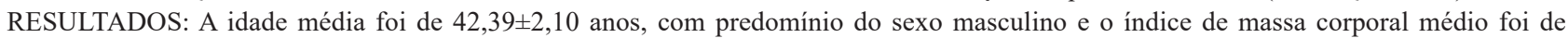
$27,55 \pm 0,76$. Níveis de atividade física predominantes foram entre moderado a alto. O sexo masculino apresentou níveis significativamente mais elevados de atividade física vigorosa $(\mathrm{p}=0,033)$ e maiores escores no WHOQOL-Bref, quando comparado ao sexo feminino.

CONCLUSÃO: Quanto maiores os níveis de atividade física desta população com deficiência visual, melhor a qualidade de vida. Os participantes tiveram uma predominância de atividade física moderada a alta, e o sexo masculino apresentou níveis maiores de atividade física em atividades vigorosas, quando comparado ao sexo feminino.

UNITERMOS: Exercício; deficiência visual; pessoas com deficiência; qualidade de vida. 
Abbreviations: BMI, body mass index; CI, confidence interval; HP, hip circumference; IPAQ short form, International Physical Activity Questionnaire short version; VI, Visual Impairment; WC, waist circumference; WHOQOL-Bref, Quality of Life Assessment Instrument; WHR, waist to hip ratio.

\section{BACKGROUND}

The visual impairment (VI) is characterized by a condition of low vision or blindness, which may result from a disease, trauma, congenital or degenerative condition $[1,2]$. Both moderate and severe VI are grouped and classified as low vision, which together with blindness represents all vision impairments [3].

Estimates say that there are about 285 million visually impaired people in the world, of whom 39 million are blind [4]. VI seems to have a substantial impact on an individual's health-related quality of life compared to other chronic conditions such as type II diabetes and hearing impairment [5]. It can significantly reduce participation in social, religious, mobility, visually intensive tasks, daily and workrelated activities [6-9].

Regular physical activity for at least 150 minutes of moderate degree per week or 75 minutes of vigorous activity per week is recommended to maintain good health and reduce the risk of mortality, and diseases, in a variety of organs of the system [10-18]. Despite these benefits, almost one-third of the adult population worldwide does not engage in physical activity, therefore, physical inactivity should be considered a global public health issue [16].

Physical inactivity is also known as a major problem among people with disabilities, especially VI, since they have difficulty accessing recreational and athletic programs and getting help in the development of adequate and safe physical recreation habits $[19,20]$.

It is believed that people with VI tend to have fewer active lifestyles and become more susceptible to diseases related to physical inactivity $[21,22]$. This may be related to barriers found in the non-inclusive practice of physical activity [23]. In this sense, the limitation in the participation of the physical activity can be related to the dependence of the help of others to be able to carry out the activity and the lack of accessibility in the neighborhood [24]. Besides that, loss of vision is also a limiting factor in the basic activities of daily living and can negatively influence quality of life, since VI requires a restructuring of these activities, such as bathing, dressing and some instrumental tasks [25].
In this sense, studies suggest that the low level of physical activity and sedentary behaviors can affect the quality of life $[26,27]$. Besides that, previous studies have demonstrated the influence of demographic factors on the practices and intensity of physical activity. However, there are still gaps in the evidence on physical activity habits and the relationship with quality of life in people with VI. Thus, this study sought to verify the relationship between physical activity habits and the quality of life of people with VI.

\section{METHODS}

It is a cross-sectional, analytical, quantitative and exploratory descriptive study. The research was carried out at the Instituto dos Cegos da Paraíba Adalgisa Cunha, located in the municipality of João Pessoa, Paraíba state. The volunteers who agreed to participate in the research provided written consent. This work was published by the Research Ethics Committee of the State University of Paraíba under protocol $\mathrm{n}$ - 2.434.275.

\section{Subjects}

The sample was non-probabilistic by accessibility, composed of 53 volunteers with visual impairment, practicing or not practicing habitual physical activity, who attended the Instituto dos Cegos da Paraiba Adalgisa Cunha.

The following inclusion criteria were considered: (1) Have uncorrected visual impairment (partial or total); (2) Be over 18 years of age; (3) Agree to participate in the survey. The following exclusion criteria were considered: (1) To have associated neurological or cognitive comorbidities; (2) Possess physical limitations of trauma-orthopedic or rheumatological origin; (3) Chemical dependency.

\section{Instruments}

The Clinical and Sociodemographic Assessment Sheet was used to characterize the participants, including gender, age, schooling, marital status, social data and occupational activities, among other characteristics as body mass index (BMI), waist circumference (WC), hip circumference (HP), waist to hip ratio (WHR) and arterial blood pressure. The International Physical Activity Questionnaire short version (IPAQ short form), validated for the brazilian population was used to evaluate physical activity 
habits [28]. The IPAQ is an instrument that assesses physical activity habits during the usual week period, which include vigorous or moderate activities performed as an exercise or as an occupational activity. Its short version consists of 8 questions that can be answered through an evaluator.

In order to measure quality of life, the Quality of Life Assessment Instrument (WHOQOL-Bref), created by the World Health Organization in 1996, comprises 26 items, where, the first two are related to the life and the other 24 related to physical, psychological, social and environmental factors. It has the score of 01 to 05 points, where the highest one is related to a better quality of life [29].

\section{Statistical analysis}

Data were expressed in percentage, mean and standard error of the mean. With the help of a statistician, the inferential analysis was done through the IBM SPSS Statistics 20 and GraphPad Prism 5.0 Statistical software. To verify the normality of the data, the Kolmogorov Smirnov test was used. To compare the variables according to sex, the student's t test was used. For the correlation between physical activity habits and quality of life variables, the Pearson correlation test was used. Linear regression was used to quantify the relation between quality of life and physical activity. The confidence interval (CI) was $95 \%$. In all analyzes, the significance level corresponding to $p<0.05$ was considered.

\section{RESULTS}

The sample consisted of 53 individuals with visual impairment, with a mean age of $42.39 \pm 2.10$ years. There was a predominance of males, single individuals and incomplete scholarity (Table 1). The majority of the participants walked with cane and had visual impairment in both eyes. The mean time of vision impairment was $29.92 \pm 2.37$ years, and the mean systolic blood pressure was $121 \pm 1.19$ and diastolic $83 \pm 1.28 \mathrm{mmHg}$. The mean Body Mass Index (BMI) was $27.55 \pm 0.76$, showing a high prevalence among individuals with pre-obesity. The mean waisthip ratio for males was $0.923 \pm 0.013$ and for females $0.855 \pm 0.027$ (Table 2).

When comparing all domains of quality of life between the sexes, using the WHOQOL-bref, it can be observed that male sex obtained significantly higher scores than the female sex, in areas of physical, psychological and environmental health (Table 3).
Table 1. Sociodemographic characteristics of individuals with visual impairment from the Instituto dos Cegos da Paraíba Adalgisa Cunha.

\begin{tabular}{lc}
\hline Variables & $\mathbf{n}(\%)$ \\
Gender & \\
$\quad$ Male & $33(62.3)$ \\
$\quad$ Female & $20(37.7)$ \\
Marital Status & \\
$\quad$ Single & $30(56.6)$ \\
Married & $14(26.4)$ \\
Divorced & $7(13.2)$ \\
Widower & $2(3.8)$ \\
Scholarity & \\
None & $2(3.8)$ \\
$\quad<8$ years & $14(26.4)$ \\
$\quad 8$ years & $7(13.2)$ \\
$>8<11$ years & $8(15.1)$ \\
$\quad=11$ years & $9(17)$ \\
$>11<15$ years & $4(7.5)$ \\
$\geq 15$ years & $9(17.0)$ \\
\hline
\end{tabular}

Table 2. Clinical and anthropometric characteristics of individuals with visual impairment at the Instituto dos Cegos da Paraíba Adalgisa Cunha.

\begin{tabular}{lc}
\hline Variables & Sample Description \\
Walking mode* & \\
Without help & $15(28.3)$ \\
Cane & $31(58.5)$ \\
Human guide & $7(13.2)$ \\
Vision impairment laterality* & \\
$\quad$ Right & $0(0)$ \\
$\quad$ Left & $1(1.9)$ \\
Both & $52(98.1)$ \\
Time of vision impairment ${ }^{\dagger}$ & $29.92 \pm 2.37$ \\
Arterial Pressure $\left(\mathrm{mmHg}^{\dagger}\right.$ & \\
Systolic & $121.13 \pm 1.19$ \\
Diastolic & $83.01 \pm 1.28$ \\
Body Mass Index ${ }^{\dagger}$ & $27.55 \pm 0.76$ \\
Waist circumference & \\
Male & \\
Female & $96.03 \pm 1.98$ \\
Hip circumference & \\
Male & $86.60 \pm 4.10$ \\
Female & \\
Waist to hip ratio & \\
Male & $103.87 \pm 1.33$ \\
Female & $100.95 \pm 2.72$ \\
\hline
\end{tabular}

* Number of participants $(\%) ;{ }^{+}$Mean \pm standard error of the mean.

Table 3. Comparison of Quality of Life domains between the sexes, using the WHOQOL-bref.

\begin{tabular}{lcccc}
\hline Domain & Sample* & Male* & Female* & $\mathbf{p}^{+}$ \\
I. Physical Health & $16.31 \pm 0.41$ & $17.11 \pm 0.48$ & $14.99 \pm 0.67$ & 0.018 \\
II. Psychological & $18.50 \pm 0.43$ & $19.20 \pm 0.52$ & $17.36 \pm 0.72$ & 0.041 \\
III. Social relationship & $20.90 \pm 0.75$ & $21.93 \pm 0.87$ & $19.20 \pm 1.31$ & 0.106 \\
IV. Environment & $15.11 \pm 0.32$ & $15.71 \pm 0.40$ & $14.13 \pm 0.47$ & 0.033 \\
Total Score & $52.18 \pm 1.07$ & $54.90 \pm 1.24$ & $47.70 \pm 1.53$ & 0.001 \\
\hline
\end{tabular}

* Mean \pm Standard error of the mean; ${ }^{+}$:Comparison by the sex variable. 
In comparison between the sexes and habits of physical activities, according to IPAQ short form, the total mean of the individuals' physical activity was $3606.50 \pm 2460.50 \mathrm{MET}$ - minutes per week. In addition, the population performance was predominant in moderate to high physical activity. Male sex, in comparison to female sex, presented higher levels of physical activity, especially in vigorous activities (Table 4).

In the correlations between quality of life and total IPAQ short form scores, it can be observed that the higher the physical activity levels of visually impaired individuals, the better the quality of life in all WHOQOL-bref domains. When correlating physical exercise intensity and quality of life, participants who performed more vigorous and moderate exercises presented better scores on the WHOQOL-bref (Table 5).

The linear regression shows a significant influence of physical activity on quality of life $\left(\mathrm{R}^{2}=0.3368\right.$; $\mathrm{P}<0.0001$ ) (Figure 1). Besides, vigorous intensity exercises show to have an influence on better quality of life aspects (Figure 2).

Table 4. Comparison of physical activity habits between the sexes according to IPAQ short form.

\begin{tabular}{lcccc}
\hline Physical activity intensity & Total frequency & Male & Female & $\mathbf{p}^{*}$ \\
Categories, $\mathrm{n}(\%)$ & & & & \\
$\quad$ High & $21(39.6)$ & $14(26.4)$ & $7(13.2)$ & \\
$\quad$ Moderate & $23(43.4)$ & $14(26.4)$ & $4(7.5)$ & \\
$\quad$ Low & $9(17)$ & $5(9.4)$ & & \\
MET - minutes per week & & & & \\
(mean \pm SEM) & & & & \\
$\quad$ Vigorous & $1383.39 \pm 199.47$ & $1762.42 \pm 289.28$ & $758.00 \pm 151.58$ & 0.159 \\
$\quad$ Moderate & $849.43 \pm 133.48$ & $830.90 \pm 112.42$ & $880.00 \pm 306.62$ & 0.717 \\
$\quad$ Walking & $1371.67 \pm 191.35$ & $1353.00 \pm 251.07$ & $1402.50 \pm 300.50$ & 0.222 \\
Total Score & $3606.50 \pm 2460.50$ & $3946.33 \pm 2552.28$ & $3040.50 \pm 2249.47$ & \\
\hline
\end{tabular}

* p: Comparison according to gender; MET: Metabolic equivalent; SEM: Standard error of the mean.

Table 5. Correlation, $(r)$ and p-values between WHOQOL-bref domains and IPAQ short form for individuals ( $\mathrm{N}=53$ ) with visual impairment.

\begin{tabular}{|c|c|c|c|c|c|c|c|c|c|c|}
\hline & & & \multirow{2}{*}{$\begin{array}{l}\text { IPAC short form } \\
\text { Total score }\end{array}$} & \multirow{2}{*}{$\begin{array}{l}\text { WHOQOL-Bref } \\
\text { Total score }\end{array}$} & \multicolumn{3}{|c|}{ IPAC short form } & \multicolumn{3}{|c|}{ WHOQOL-Bref } \\
\hline & & & & & $\begin{array}{c}\text { Vigorous } \\
\text { Physical Activity }\end{array}$ & $\begin{array}{c}\text { Moderate } \\
\text { Physical Activity }\end{array}$ & Walking & $\begin{array}{l}\text { Physical } \\
\text { Healthy }\end{array}$ & $\begin{array}{c}\text { Social } \\
\text { Relationship }\end{array}$ & Environment \\
\hline \multirow{2}{*}{\multicolumn{2}{|c|}{$\begin{array}{l}\text { WHOQOL-Bref } \\
\text { Total score }\end{array}$}} & r & .580 & & & & & & & \\
\hline & & p-value & .000 & & & & & & & \\
\hline \multirow{6}{*}{ 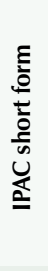 } & \multirow{4}{*}{$\begin{array}{l}\text { Vigorous Physical } \\
\text { Activity } \\
\text { Moderate Physical } \\
\text { Activity }\end{array}$} & $r$ & .754 & .586 & & & & & & \\
\hline & & p-value & .000 & .000 & & & & & & \\
\hline & & $r$ & .612 & .265 & .409 & & & & & \\
\hline & & p-value & .000 & .056 & .002 & & & & & \\
\hline & \multirow{2}{*}{ Walking } & $r$ & .553 & .229 & .005 & -.042 & & & & \\
\hline & & $\mathrm{p}$-value & .000 & .099 & .971 & .766 & & & & \\
\hline \multirow{8}{*}{ 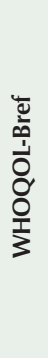 } & \multirow{2}{*}{ Physical Healthy } & r & .414 & .833 & .379 & .230 & .176 & & & \\
\hline & & $p$-value & .002 & .000 & .005 & .098 & .208 & & & \\
\hline & \multirow{2}{*}{ Psychological } & $r$ & .469 & .886 & .494 & .378 & .051 & .764 & & \\
\hline & & $p$-value & .000 & .000 & .000 & .005 & .717 & .000 & & \\
\hline & \multirow{2}{*}{ Social Relationship } & $r$ & .353 & .692 & .343 & .242 & .097 & .716 & .754 & \\
\hline & & $p$-value & .010 & .000 & .012 & .081 & .491 & .000 & .000 & \\
\hline & \multirow{2}{*}{ Environment } & r & .372 & .710 & .408 & .029 & .211 & .540 & .515 & .400 \\
\hline & & p-value & .006 & .000 & .002 & .837 & 130 & .000 & .000 & .003 \\
\hline
\end{tabular}


$R^{2}=0.3368 ; P<0.0001$

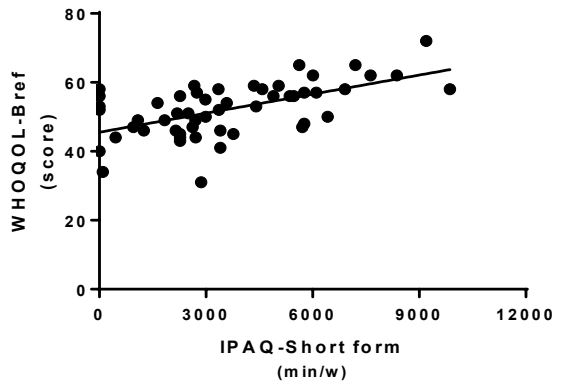

$\mathrm{R}^{2}=0.1714 ; \mathrm{P}=0.0021$

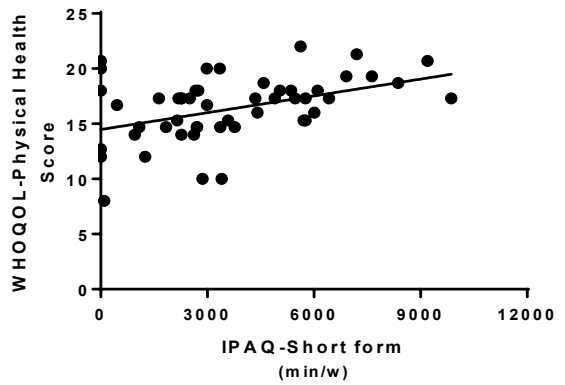

$\mathrm{R}^{2}=0.2203 ; \mathrm{P}=0.0004$

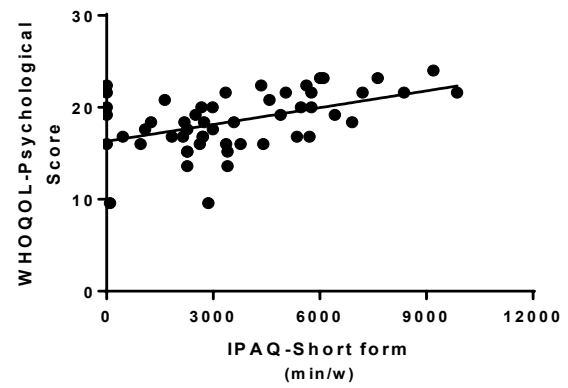

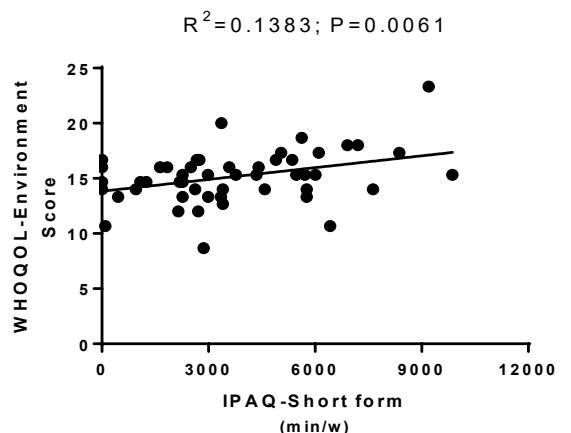

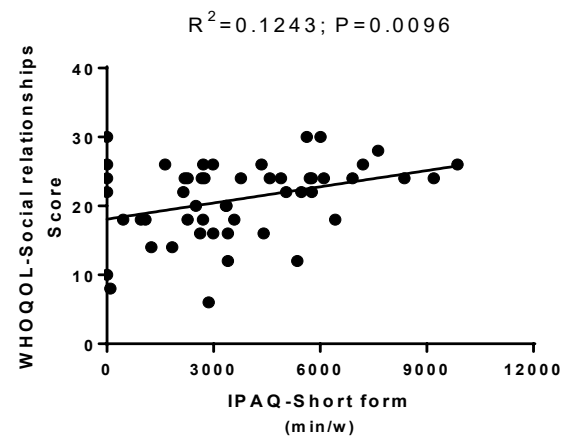

Figure 1. Linear regression between all WHOQOL-bref domains and IPAQ short form total scores.
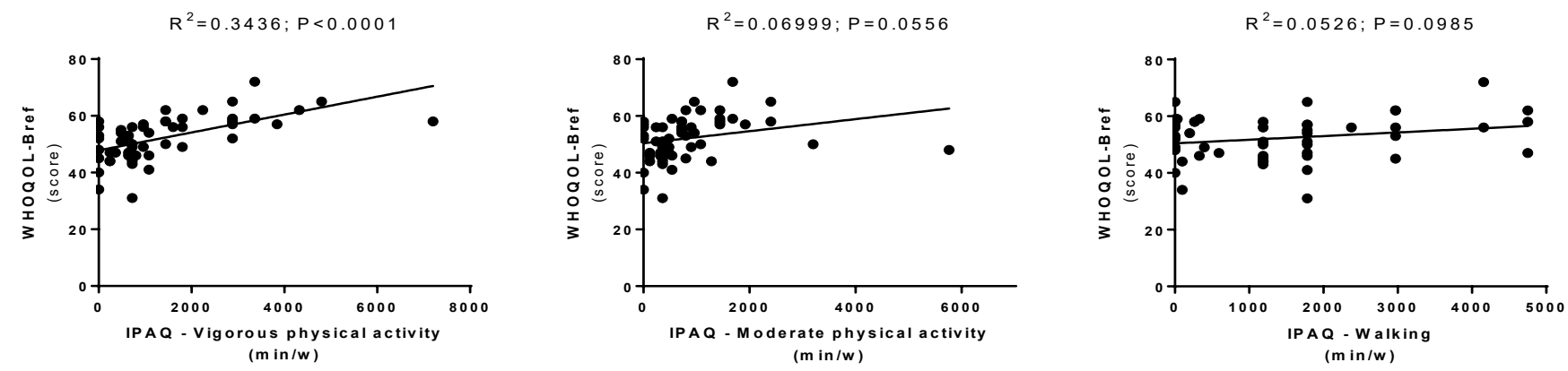

Figure 2. Linear regression between WHOQOL-bref total scores and physical exercise intensity, according to the IPAQ short form.

\section{DISCUSSION}

The purpose of this study was to provide physics and quality of life data for people with visual impairment. Participants showed moderate to high levels of physical activity being greater significance in males. In addition, the higher and more intense levels of physical activity in this population, the better quality of life.

In this study, there was a predominance of males, walking with walking stick and having both eye involvement. VI affects people of all ages and both sexes $[30,31]$. Previous studies are largely inconclusive as to the relation of sociodemographic factors in adults with VI, which show a high prevalence in both males and females [31-33].

It is observed in this study that the sample consisted of adults with mean BMI classified as pre-obese. In the same sense, the Haegele et al. study evaluated 147 individuals with visual impairment of average age of $44.33 \pm 15.3$ years and observed that the mean BMI was $27.59 \pm 6.52$, within a variance of overweight individuals. Another study showed that $73.1 \%$ of the individuals with VI evaluated were overweight [33].

Physical activity levels were considered moderate and high in the study population. These results are in agreement with studies that show participants with VI were physically active in moderate to vigorous 
activities, however, it is important to observe issues that involve sedentarism in this population [34]. Nutrition covariables weren't controlled in our study. As it's possible that they influence directly the population's BMI, they could explain the pre-obese classification result. Besides that, the IPAQ short form is a self-report instrument and can present memory and observation bias.

Previous studies have shown divergent results in the levels of physical activity between male and female with VI. While some indicate that there are no significant differences in physical activity levels between men and women, others report that males were more active and participatory in physical activities than females $[9,35]$. The latter corroborate with the results found in the present study, where men presented higher levels than women, mainly in vigorous activities. However, it should be considered that in our sample there were more men than women, this may have impacted the results found.

On the other hand, many factors may explain the influence of sex on physical activity levels, for example, the type of physical activity performed, whether occupational or recreational, the mode and time spent in such activities [34]. Moreover, the activities developed in the work environment by men tend to promote a greater accumulation of minutes in occupational physical activities [36]. These results are consistent with other studies, which show that men are significantly more active than adult women with VI or without disability [34,37].

VI has a significant impact on quality of life compared to other chronic conditions [5]. A study shows that, in general, individuals presented a mean score below the classification of the perceived quality of life assessment established for a Brazilian population with a 60 -point cut-off score [38].

When evaluated by sex, men presented a better perception of the quality of life than women. In this sense, studies have shown that people with female VI have lower quality of life scores when compared to males [39].

In the present study it can be observed that higher levels of physical activity are related to a better perception in the 4 domains of quality of life evaluated by the WHOQOL-Bref. In line with these findings, previous studies have presented similar results where levels of physical activity can improve quality of life, when evaluated by self-report instruments $[34,40]$.
This study presented results on the levels of physical activity and quality of life in individuals with VI. Some limitations may be highlighted in sequence. Although the instruments used for evaluation are reliable and validated nationally and internationally, allowing direct and effective investigation of this population, these measures provide self-report data that can make the results more subjective. Another limitation is the non-inclusion of a control group without VI that could provide more concise results as to the influence of the investigated condition.

In conclusion, the higher the level of physical activity, the better the quality of life performance of the individuals studied. Showing that physical activity plays an important role in the quality of life especially in the motivational and environmental aspects, besides the benefits to physical health already known. It should be considered that the predominance of moderate to high physical activity in male when compared with the female, especially in vigorous activities, could be explained by the number of male individuals and the type of activity performed, such as, work activities. Future studies that include control group are needed to investigate physical activity habits and quality of life in people with visual impairment and could provide more concise results as to the influence of the condition investigated.

\section{NOTES}

This study was apresented at the Congresso Nacional de Envelhecimento Humano, 2018, Brazil.

Funding

This study did not receive financial support from outside sources.

Conflicts of interest disclosure

The authors declare no competing interests relevant to the content of this study.

\section{Authors' contributions}

All the authors declare to have made substantial contributions to the conception, or design, or acquisition, or analysis, or interpretation of data; and drafting the work or revising it critically for important intellectual content; and to approve the version to be published.

Availability of data and responsibility for the results

All the authors declare to have had full access to the available data and they assume full responsibility for the integrity of these results. 


\section{REFERENCES}

1. World Health Organization. International statistical classification of diseases and related health problems 10th revision [Internet]. Geneva: WHO; 2016 [cited 2019 Mar 7]. Available from: https://icd.who.int/browse10/2016/en

2. Adigun K, Oluleye TS, Ladipo MM, Olowookere SA. Quality of life in patients with visual impairment in Ibadan: a clinical study in primary care. J Multidiscip Healthc. 2014;7:173-8. http://dx.doi.org/10.2147/JMDH.S51359

3. World Health Organization. Blindness and vision impairment [Internet]. Geneva: WHO; 2018 [cited 2019 Mar 7]. Available from: http://www.who.int/mediacentre/factsheets/fs282/en/

4. Pascolini D, Mariotti SP. Global estimates of visual impairment: 2010. Br J Ophthalmol. 2012(5);96:614-18. http://dx.doi.org/10.1136/bjophthalmol-2011-300539

5. Langelaan M, de Boer MR, van Nispen RM, Wouters B, Moll AC, van Rens GH. Impact of visual impairment on quality of life: a comparison with quality of life in the general population and with other chronic conditions. Ophthalmic Epidemiol. 2007;14(3):119-26. http://dx.doi.org/10.1080/09286580601139212

6. West SK, Rubin GS, Broman AT, Muñoz B, Bandeen-Roche K, Turano K. How does visual impairment affect performance on tasks of everyday life? The SEE project. Arch Ophthalmol. 2002;120(6):774-80. http://dx.doi. org/10.1001/archopht.120.6.774

7. Weih LM, Hassell JB, Keeffe J. Assessment of the impact of vision impairment. Invest Ophthalmol Vis Sci. 2002;43(4):927-35.

8. Lamoureux EL, Hassell JB, Keeffe JE. The determinants of participation in activities of daily living in people with impaired vision. Am J Ophthalmol. 2004;137(2):265-70. http://dx.doi.org/10.1016/j.ajo.2003.08.003

9. Lee M, Zhu W, Ackley-Holbrook E, Brower DG, McMurray B. Calibration and validation of the Physical Activity Barrier Scale for persons who are blind or visually impaired. Disabil Health J. 2014;7(3):309-17. http://dx.doi. org/10.1016/j.dhjo.2014.02.004

10. Pate RR, Pratt M, Blair SN, Haskell WL, Macera CA, Bouchard C, Buchner D, Ettinger W, Heath GW, King AC, Kriska A, Leon AS, Marcus BH, Morris J, Paffenbarger RS Jr, Patrick K, Pollock ML, Rippe JM, Sallis J, Wilmore JH. Physical activity and public health: a recommendation from the Centers for Disease Control and Prevention and the American College of Sports Medicine. JAMA. 1995;273(5):402-7. http://dx.doi.org/10.1001/ jama.1995.03520290054029

11. Laurin D, Verreault R, Lindsay J, MacPherson K, Rockwood K. Physical activity and risk of cognitive impairment and dementia in elderly persons. Arch Neurol. 2001;58(3):498-504. http://dx.doi.org/10.1001/ archneur.58.3.498

12. Warburton DE, Nicol CW, Bredin SS. Health benefits of physical activity: the evidence. CMAJ. 2006;174(6):801-9. http://dx.doi.org/10.1503/cmaj.051351

13. Haskell WL, Lee IM, Pate RR, Powell KE, Blair SN, Franklin BA, Macera CA, Heath GW, Thompson PD, Bauman A. Physical activity and public health: updated recommendation for adults from the American College of Sports Medicine and the American Heart Association. Med Sci Sports Exerc. 2007;39(8):1423-34. http://dx.doi.org/10.1249/ mss.0b013e3180616b27

14. Marmeleira JF, Godinho MB, Fernandes OM. The effects of an exercise program on several abilities associated with driving performance in older adults. Accid Anal Prev. 2009;41(1):90-7. http://dx.doi.org/10.1016/j.aap.2008.09.008

15. Garber CE, Blissmer B, Deschenes MR, Franklin BA, Lamonte MJ, Lee IM, Nieman DC, Swain DP; American College of Sports Medicine. Quantity and quality of exercise for developing and maintaining cardiorespiratory, musculoskeletal, and neuromotor fitness in apparently healthy adults: guidance for prescribing exercise. Med Sci Sports Exerc. 2011;43(7):1334-59. http://dx.doi.org/10.1249/MSS.0b013e318213fefb

16. Barbosa DG, Andrade RD, Pelegrini A, Felden ÉP. Rating of perceived capacity: a proposal to predict adequate levels of physical activity in visually impaired individuals. J Sports Med Phys Fitness. 2017;59(2):274-82. http://dx.doi. org/10.23736/S0022-4707.17.08070-7

17. Booth FW, Gordon SE, Carlson CJ, Hamilton MT. Waging war on modern chronic diseases: primary prevention through exercise biology. J Appl Physiol. 2000;88(2):774-87. http://dx.doi.org/10.1152/jappl.2000.88.2.774

18. Booth FW, Lees SJ. Fundamental questions about genes, inactivity, and chronic disease. Physiol Genomics. 2007;28(2):146-57. http://dx.doi.org/10.1152/physiolgenomics.00174.2006 
19. US Department of Health and Human Services. Physical activity and health: a report of the Surgeon General. Atlanta: US Department of Health and Human Services, Public Health Service, CDC, National Center for Chronic Disease Prevention and Health Promotion; 1996.

20. Capella-McDonnall M. The need for health promotion for adults who are visually impaired. J Vis Impair Blind. 2007;101:133-45. http://dx.doi.org/10.1177/0145482X0710100302

21. Longmuir PE, Bar-Or O. Factors influencing the physical activity levels of youths with physical and sensory disabilities. Adapt Phys Activ Q. 2000;17(1):40-53. http://dx.doi.org/10.1123/apaq.17.1.40

22. Holbrook EA, Caputo JL, Perry TL, Fuller DK, Morgan DW. Physical activity, body composition, and perceived quality of life of adults with visual impairments. J Vis Impair Blind. 2009;103(1):17-29. http://dx.doi.org/10.1177/ $0145482 X 0910300104$

23. Morgado FFR, Campana ANNB, Morgado JJM, Fortes LS, Tavares MCGCF. How persons with congenital blindness perceive facilitators and barriers for the practice of physical activities. Rev Bras Educ Espec. 2013;19(3):379-94. http://dx.doi.org/10.1590/S1413-65382013000300006

24. Jaarsma EA, Dekker R, Koopmans SA, Dijkstra PU, Geertzen JHB. Barriers to and facilitators of sports participation in people with visual impairments. Adapt Phys Activ Q. 2014;31(3):240-64. http://dx.doi.org/ $10.1123 / 2013-0119$

25. Brown RL, Barrett AE. Visual impairment and quality of life among older adults: an examination of explanations for the relationship. J Gerontol B Psicol Sci Soc Sci. 2011;66B(3):364-73. http://dx.doi.org/10.1093/geronb/ gbr015

26. Pucci GCMF, Rech CR, Fermino RC, Reis RS. Association between physical activity and quality of life in adults. Rev Saúde Pública. 2012;46(1):166-79. http://dx.doi.org/10.1590/S0034-89102012000100021

27. Anokye NK, Trueman P, Green C, Pavey TG, Taylor RS. Physical activity and health related quality of life. BMC Public Health. 2012;12:624. http://dx.doi.org/10.1186/1471-2458-12-624

28. Matusdo S, Araújo T, Matsudo V, Andrade D, Andrade E, Oliveira IC, Braggion G. Questionário internacional de atividade física (IPAQ): estudo de validade e reprodutibilidade no brasil. Rev Bras Atividade Física Saúde. $2001 ; 6(2): 5-12$.

29. World Health Organization. WHOQOL-BREF: introduction, administration, scoring and generic version of the assessment: field trial version. Geneva: WHO; 1996.

30. Castro SS, César CLG, Carandina L, Barros MBA, Alves MCGP, Goldbaum M. Deficiência visual, auditiva e física: prevalência e fatores associados em estudo de base populacional. Cad Saúde Pública. 2008;24(8):1773-82. http://dx.doi.org/10.1590/S0102-311X2008000800006

31. Bourne RRA, Flaxman SR, Braithwaite T, Cicinelli MV, Das A, Jonas JB, Keeffe J, Kempen JH, Leasher J, Limburg H, Naidoo K, Pesudovs K, Resnikoff S, Silvester A, Stevens GA, Tahhan N, Wong TY, Taylor HR; Vision Loss Expert Group. Magnitude, temporal trends, and projections of the global prevalence of blindness and distance and near vision impairment: a systematic review and meta-analysis. Lancet Glob Health. 2017;5(9):e888-97. http://dx.doi.org/10.1016/S2214-109X(17)30293-0

32. Silva RBP, Marques AC, Reichert FF. Objectively measured physical activity in Brazilians with visual impairment: description and associated factors. Disabil Rehabil. 2018;40(18):2131-7. http://dx.doi.org/10.1080/09638288.2017. 1327984

33. Haegele JA, Kirk TN, Zhu X. Self-efficacy and physical activity among adults with visual impairments. Disabil Health J. 2018;11(2):324-9. http://dx.doi.org/10.1016/j.dhjo.2017.10.012

34. Haegele JA, Zhu X, Lee J, Lieberman LJ. Physical activity for adults with visual impairments: impact of sociodemographic factors. Eur J Adapt Phys Act. 2016;9(1):3-14. http://dx.doi.org/10.5507/euj.2016.001

35. Marmeleira JF, Laranjo L, Marques O, Pereira C. Physical activity patterns in adults who are blind assessed by accelerometry. Adapt Phys Activ Q. 2014;31(3):283-96. http://dx.doi.org/10.1123/apaq.2013-0039

36. Holtermann A, Hansen JV, Burr H, Søgaard K, Sjøgaard G. The health paradox of occupational and leisure-time physical activity. Br J Sports Med. 2012;46(4):291-5. http://dx.doi.org/10.1136/bjsm.2010.079582

37. Carlson SA, Fulton JE, Pratt M, Yang Z, Adams EK. Inadequate physical activity and health care expenditures in the United States. Prog Cardiovasc Dis. 2015;57(4):315-23. http://dx.doi.org/10.1016/j.pcad.2014.08.002 
38. Silva PA, Soares SM, Santos JF, Silva LB. Cut-off point for WHOQOL-bref as a measure of quality of life of older adults. Rev Saúde Pública. 2014;48(3):390-7. http://dx.doi.org/10.1590/S0034-8910.2014048004912

39. Khorrami-Nejad M, Sarabandi A, Akbari M-R, Askarizadeh F. The impact of visual impairment on quality of life. Med Hypothesis Discov Innov Ophthalmol. 2016;5(3):96-103.

40. Łabudzki J, Tasiemski T. Physical activity and life satisfaction in blind and visually impaired individuals. Hum Mov. 2013;14(3):210-6. https://doi.org/10.2478/humo-2013-0025 